\title{
What's In the Manuscripts of Timbuktu? A Survey of the Contents of 31 Private Libraries
}

\author{
Charles C. Stewart $\odot$
}

\begin{abstract}
The Arabic manuscripts of Timbuktu have received considerable publicity during the past 25 years, yet their contents remain largely unknown. Since 2012, an inventory of nearly 350,000 Timbuktu manuscripts in private libraries has been underway, and the contents of those libraries are now accessible in the West African Arabic Manuscript Database (WAAMD). This analysis examines 31 of the 35 libraries and in addition to reporting on their contents, notes challenges in accessing incompletely identified works, and compares the manuscripts with other West African collections.
\end{abstract}

Résumé: Les manuscrits arabes de Tombouctou ont fait l'objet d'une publicité considérable au cours des 25 dernières années, mais leur contenu reste largement méconnu. Depuis 2012, un inventaire de près de 350000 manuscrits de Tombouctou dans des bibliothèques privées est en cours et le contenu de ces bibliothèques est désormais accessible dans la base de données des manuscrits arabes de l'Afrique de l'Ouest (WAAMD). Cette analyse examine 31 des 35 bibliothèques et, en plus de rendre compte de leur contenu, note les difficultés d'accès aux œuvres incomplètement identifiées et compare les manuscrits avec d'autres collections d'Afrique de l'Ouest.

History in Africa, Volume 48 (2021), pp. 279-308

Charles C. Stewart is Professor Emeritus at the University of Illinois at UrbanaChampaign. He began a bilingual, open access union catalogue of West African manuscripts thirty years ago, which is now the West African Arabic Manuscript Database (WAAMD), hosted at University of California, Berkeley at https:// waamd.lib.berkeley.edu/, and recently compiled vol. 5 in the Arabic Literature of Africa series, The Writings of Mauritania and the Western Sahara (Leiden: Brill, 2015). His recent writing focuses on the Arabic manuscript culture of West Africa. E-mail: stewartcharles99@yahoo.com

(C) The Author(s), 2021. Published by Cambridge University Press. This is an Open Access article, distributed under the terms of the Creative Commons Attribution licence (http://creativecommons.org/licenses/by/4.0/), which permits unrestricted re-use, distribution, and reproduction in any medium, provided the original work is properly cited. 


\section{Introduction $^{1}$}

No single body of primary sources in the literary heritage of sub-Saharan Africa has attracted as much attention or attained as much celebrity during the past 25 years as the fabled Arabic manuscripts of Timbuktu. ${ }^{2}$ The Road to Timbuktu, the film series produced by Henry Louis Gates, Jr. featured them, ${ }^{3}$ international conferences and major books focused on them, ${ }^{4}$ the Tombouctou Manuscripts Project was launched in 2003, and the South Africa-Mali Project: Timbuktu Manuscripts was dedicated to their recovery and documentation. ${ }^{5}$ With the Islamist intervention in Timbuktu in 2012 came the threat of their destruction and widespread international press coverage. Two books have been written on that episode and the heroic efforts made to safeguard them. ${ }^{6}$

${ }^{1}$ I am indebted to Dmitry Bondarev, Susana Molins Lliteras, Mauro Nobili, and Shamil Jeppie for their comments on early versions of this paper.

2 For an introduction, see Abdel Kader Haidara, "An Overview of the Major Manuscript Libraries in Timbuktu" in Graziano Kratli and Ghislaine Lydon (eds.), The Trans-Saharan Book Trade (Leiden: Brill, 2011), 241-264. As one of the most effective cultural entrepreneurs responsible for bringing world attention to the manuscripts of Timbuktu, Abdel Kader Haidara describes his role in attracting funding for manuscript cataloguing and preservation there from the early-1990s and his successful efforts to enlist Henry Louis Gates in 1997 who, in turn, paved the way for Mellon Foundation funding of a facility to house Abdel Kader's manuscripts and his "Association pour la Sauvegarde et la Valorisation des Manuscrits a Tombouctou." Abdel Kader was also successful in attracting funding from the al-Furqan Foundation in London in 1997. His organization of private library custodians morphed into the Association pour la Sauvegarde et la Valorisation des Manuscrits pour la Defense de la Culture Islamique (SAVAMA-DCI) by 2005 when he attracted Ford Foundation resources and, two years later, funding from the Juma al-Majid Heritage and Cultural Center in Dubai. It is the contents of the 35 libraries in SAVAMA-DCI that are discussed in this article. The best overview of the Timbuktu manuscript story is Jean-Louis Triaud, "Autour des manuscrits de Tombouctou Un état des lieux," Sociétés politiques comparées 44 ( Jan.-April 2018).

3 "The Road to Timbuktu" in Wonders of the African World (with Henry Louis Gates,Jr.) (1999), where we learn about the "rich literary tradition [of Timbuktu]" was followed in 2009 by three documentaries by different production crews: The Ancient Astronomers of Timbuktu (directed by Sharron Hawkes), The Manuscripts of Timbuktu (directed by Zola Maseko), and The Lost Libraries of Timbuktu (produced by the BBC).

${ }^{4}$ Most spectacular is J.O. Hunwick's The Hidden Treasures of Timbuktu (London: Thames \& Hudson, 2008).

5 The Tombouctou Manuscript Project at the University of Cape Town; the proceedings of an international conference in 2005, published as The Meanings of Timbuktu (Shamil Jeppie and Souleymane Bachir Diagne, eds.; Cape Town: HSRC Press, 2008), well summarizes the anticipation and expectations of Africa's rich literary past locked within the manuscripts of Timbuktu.

${ }^{6}$ Joshua Hammer, The Bad-Ass Librarians of Timbuktu (New York: Simon and Schuster, 2016), [a film rendition of this best-selling book is now in production], and 
All told, during the past quarter-century, multiple major grants totaling millions of dollars from Europe, the Gulf states, Iran, and the U.S. have been generated to catalogue and preserve Timbuktu's literary heritage. This notoriety, at the expense of similar manuscript libraries as near as Djenné or further afield in neighboring southern Mauritania and Niger, has triggered some justified grumbling from students of other repositories of Islamic learning in West Africa. But only one site carries the quasi-mystical appellation of "Timbuktu," that has played so large in the European imagination for centuries. Nor have other sites been blessed with comparable cultural entrepreneurs who have been so effective in linking the story of Timbuktu's scholarly past with twentiethcentury manuscript writing. Indeed, the city's three sixteenth-century scholarly lineages, upon which most of its historic fame rests, are well documented, but even better advertised (and pitched to funding agencies) are the vast numbers of Arabic manuscripts in and around Timbuktu today. A somewhat romanticized medieval scholarly past has long been assumed to be connected to the current manuscripts of Timbuktu; recent cataloguing of contemporary manuscript libraries there shows little if any link to that storied past.

Oddly, with all the attention they have received, and despite cataloguing efforts at the national manuscript collection in Timbuktu that dates back at least thirty years, the actual contents of the private libraries in Timbuktu remain largely unknown. ${ }^{7}$ Much ink has been expended on claims about the numbers of manuscripts in and around Timbuktu and projections of manuscripts waiting to be discovered. ${ }^{8}$ Almost no attention has been paid to what

Charlie English, The Storied City: The Quest for Timbuktu (New York: Riverhead, 2017); for the best summary of these accounts and others that brought the manuscripts of Timbuktu to renewed international attention in 2013 see Bruce Hall, "Rethinking the Place of Timbuktu in the Intellectual History of Muslim West Africa," in Toby Green and Benedetta Rossi (eds.), Landscapes, Sources and Intellectual Projects of the West African Past (Leiden: Brill, 2018), 239-257.

7 The first handlist for the national collection at the Centre de Documentation et de Recherches Historiques Ahmad Baba (CEDRAB), now the Institut des Hautes Etudes et de Recherche Islamique Ahmed Baba (IHERIAB), was developed in the 1980s, and a decade later the database that has become the West African Arabic Manuscript Database (WAAMD) followed. In 1992, CEDRAB Director Mahmoud Zoubayr approved the input of their handlist into the WAAMD database. Soon after, al-Furqan Foundation was also contracted by CEDRAB to catalogue the contents of the national collection, published in 1995. That collection, now much expanded, has recently been re-catalogued and printed locally as: Fihris makhtūtāt Ma'had Aḥmad Bābā lil-Dirāsāt al-'Ulyā wa-al-Buhūth al-Islāmīyah (2016).

${ }^{8}$ Several critiques of some of the more outlandish claims about millions of manuscripts in and around Timbuktu have been published; see Jean-Louis Triaud, “Tombouctou ou le Retour du Mythe: L'Exposition Médiatique des Manuscrits de Tombouctou" in D. Gary-Tounkara and D. Nativel,( eds.), Afrique des Savoirs au Sud du Sahara (Paris: Karthala, 2012), 201-222, and Bruce Hall, "Rethinking the Place of Timbuktu," 240 et seq. 
is in the manuscripts, what function or knowledge practice they served, and the levels and kinds of learning, teaching, and scholarship they represent. This can be attributed in part to the wonder and mystique that surrounds all manuscript libraries: they tend to be inaccessible and opaque, and private manuscript libraries in the southern Sahara are not immune from this. Contributing to our ignorance in West Africa, until recently, has been the absence of comparative data against which library holdings can be evaluated. In the absence of such comparisons, all authors, all manuscripts, all libraries are unique; little wonder that the Timbuktu libraries and manuscripts have attracted such attention from film producers. What is unique or original or commonplace or mundane can only be known by comparing works and libraries across the large sweep of West Africa's manuscript culture.

\section{The SAVAMA-DCI Libraries and Comparative Data from the West African Arabic Manuscript Database}

Today, thanks to an ambitious project undertaken by a Malian consortium of private libraries, the Sauvegarde et Valorisation des Manuscrits pour la Défense de la Culture Islamique, (SAVAMA-DCI), we can begin to answer: What's in the manuscripts of Timbuktu? Admittedly, SAVAMA-DCI represents only 35 of the private libraries in Timbuktu, but the volume of manuscripts inventoried in this project makes it a plausible cross-section of that city's manuscript culture. The manuscripts number nearly 350,000 and SAVAMA-DCI, in collaboration with The Centre for the Study of Manuscript Cultures, University of Hamburg (CSMC), and the Hill Museum and Manuscript Library (HMML), St. John's University, St. Cloud Minnesota, have been recording all of the manuscripts. Those inventories, from 35 member libraries, have been compiled during the past five years. In 2018, the SAVAMA-DCI inventories were made available to the University of California Berkeley West African Arabic Manuscript Database (WAAMD) and all those records are now available at the WAAMD site (https://waamd.lib.berkeley. $\mathrm{edu} /)^{9}{ }^{9}$ The analysis that follows comes from preparing the SAVAMA-DCI data for WAAMD, where 31 of the 35 SAVAMA inventories can now be found. For the first time, we can compare this cross-section of the manuscripts of Timbuktu with holdings in a dozen other West African public and private libraries. Although the roughly 20,000 SAVAMA-DCI records that contain author information make up only about 7 percent of the Timbuktu manuscripts inventoried, the number of records provides a statistically valid sample from which tentative conclusions can be drawn.

9 The original SAVAMA-DCI library inventories can also be accessed at the CSMC site: https://www.manuscript-cultures.uni-hamburg.de/timbuktu/handlists_ e.html 
According to its founder, Abdel Kader Haidara, the idea of the SAVAMADCI consortium dates from 1991 or 1996, and the construction of a building to house private collections in Timbuktu began in 1999, then was renovated and expanded in 2005, and again in 2007, each with new infusions of external financial aid. ${ }^{10}$ SAVAMA-DCI does not include the national collection at IHERIAB, noted above, nor does it include at least two other, important private libraries there: The Fondo Kati and Imam Assuyuti Library. ${ }^{11}$ But the SAVAMA-DCI library inventories do represent the largest number of private libraries from a single locale in West Africa that have yet been accessible to researchers. And these are the same libraries that have been at the core of "marketing" the Timbuktu libraries for external support to preserve and catalogue Timbuktu's manuscript culture during the past 25 years. The SAVAMA-DCI inventories are comprehensive compilations of all written material uncovered in the participating libraries, and this sets them apart from most of the other libraries accessible through WAAMD. With two exceptions, all previous library records entered in WAAMD were selective: previous libraries entered in the database have privileged manuscripts in the Islamic disciplines written by local or regional authorities and classical works. ${ }^{12}$ Ephemera, the one and two folio items copied from manuscripts, which I have called "study sheets" below, some with identifiable authors, others with no known author, were largely ignored in most of the WAAMD collections. ${ }^{13}$ Similarly, short therapeutic and prophylactic formulae in the

10 For a full description see Abdel Kader Haidara, "An overview" (2011) and his "The state of manuscripts in Mali and efforts to preserve them" in The Meanings of Timbuktu (2008). In his 2008 chapter, he dates the beginning of SAVAMA-DCI to 1996; in his 2011 chapter it is 1991. Similarly, the number of libraries in the consortium have changed, and their holdings have generally increased, during the past 30 years. Listed in Appendix B are the current 35 members of SAVAMA-DCI.

11 For catalogues of the Fondo Kati, see https://www.worldcat.org/title/ khazain-i-maktum-i-tumbuktu-fihristvarah-i-umumi-i-nuskhahha-yi-khatti-i-fandikatikhandan-i-al-quti and for Imam Assuyuti, https://www.worldcat.org/title/fihrist-inuskhahha-yi-khatti-i-kitabkhanah-i-al-imam-al-suyuti-tumbuktu.

12 The two exceptions are the "Kano" collection of manuscripts in the Northwestern University Library acquired in Northern Nigeria in the 1970s, which includes WAAMD entries \#2615-5948, labeled "Falke" from the "Umar Falke library, and the "Segou" collection, the library confiscated by the French in Segou from the family of al-Haij 'Umar Tal in 1890, added to WAAMD in 1988/89 from the catalogue prepared in 1985 by Noureddine Ghali, Sidi Mohamed Mahibou, and Louis Brenner, Inventaire de la Bibliothèque 'Umarienne de Segou (Paris: CNRS, 1985). Both these libraries are inclusive of all written work found in them.

13 The "study sheets," discussed below, are short excerpts from the canon and local authorities that are found in large number in SAVAMA-DCI libraries and point to the likelihood that they were study or memorization aids from recent times when paper was plentiful. 
esoteric sciences lacking an author attribution, like talismans and other letter, word, or numeric devices written for their predictive value or to resolve personal problems, were largely ignored by cataloguers. WAAMD, from the outset, has conscientiously replicated all records from the collections included, but in doing this it has also been held hostage to the judgement of their cataloguers on what constitutes a "manuscript." This has generally resulted in privileging manuscripts with known authors and manuscripts that fall within the classic corpus of the Islamic sciences. Manuscripts with "author unknown" regularly appear in catalogues that make up the WAAMD listings, but prior to the SAVAMA-DCI inventories there was no collection in WAAMD that listed more than 20 percent of the contents of a library as works by "unknown author." In contrast, the inventories in the SAVAMA-DCI project include a much higher number of unknown authors, typically 90-95 percent, including many one and two folio items lacking in searchable data points, i.e. records with no author, an attributed title, and subject identification that describes a work's affect rather than its content (discussed below).

The total number of items inventoried across the 35 SAVAMA-DCI libraries is 348,531 ; about 7 percent of that number, or 25,000 have attributed authors, many of whom are repeated within and across inventories. ${ }^{14}$ About two-thirds of those authors' names can be found in other WAAMD collections. Among the new names to the database, roughly half come from correspondence (names of letter writers as well as letter recipients are noted in WAAMD records), and the other half are new names, mainly local authors. This includes authors who are identified only by a single name ("Muhammad" or "Ahmad"), and who may only be fully known at some future date when script-recognition technologies can be applied to the documents. Similarly, more sophisticated technologies and/or methods of cataloguing will be required to tap the slightly over 300,000 items that are one and two folios in length, lacking authors, and with attributed titles. These one and two folio works make up 75 percent of the total items inventoried in the SAVAMA libraries, and they can be found in their original spreadsheet form for each library, accessible at a link found in the library's description under the WAAMD tab "Manuscript Collections included." There, readers can find the original entries, alphabetized by attributed titles (the most descriptive part of the entries). Longer works, exceeding two folios but also lacking author attribution, have been entered in WAAMD (about 33,000 records across all libraries). These longer works are the most likely to be identified by author and/or title when digital copies become available through the HMML project.

14 At the time this analysis was done (fall 2019), 31 of the 35 SAVAMA-DCI libraries had been entered in WAAMD, two of the inventories were not yet completed, one was under revision, and the Mamma Haidara Library was being processed. A summary of all libraries and their statistics appears in Appendix B. 
Across all the SAVAMA inventories there are approximately 180 unique author names, after duplicates are eliminated. That number does not include correspondence (there may be as many as 2,000 unique author names in letters), but it does include many incomplete names. ${ }^{15}$ If we assume that the most frequently found author names are indicators of the core of a scholastic tradition, there are 55 authors whose works appear in at least half of the 31 libraries surveyed here. ${ }^{16}$ Those authors are listed in Appendix A, where they are compared with all ninety SAVAMA authors who also appear in the Hall and Stewart "core curriculum" analysis of the most frequently found authors and texts across West Africa. ${ }^{17}$

Hall and Stewart's "Core Curriculum" methodology suggests that commonly found authors and texts across multiple libraries point to the probability that they were central to instruction and learning. Its corollary is that the absence or infrequency of an author or a subject implies work that was not part of the scholarly corpus. The "core curriculum" analysis was based on over eighty private library holdings across West Africa and roughly 21,000 manuscripts that had been entered in the WAAMD prior to 2011. We found 223 titles repeated in adequate numbers and widely distributed from the Atlantic to Lake Chad to permit us to tag them as West Africa's historic "core curriculum." The SAVAMA library inventories provide us with a rare opportunity to conduct a similar analysis since, unlike the sampling technique devised for the "core curriculum" analysis (based on library inventories that were biased in favor of the classical canon), the comprehensive inventories of the Timbuktu libraries permit a survey of all extant authored work in these libraries. ${ }^{18}$ Thanks to the input protocol for the SAVAMA inventories, each time an author's writing is identified, it is listed as a separate record, whether a single folio, a portion of the work, or a complete manuscript. It is well-known that manuscript libraries commonly contain portions of works, and that manuscripts were acquired both as complete works as well as in sections or chapters.

Clearly, from their small numbers of pages, some of the SAVAMA entries refer to segments of larger works. But many SAVAMA inventories also include what we are calling "study sheets," each one catalogued as a separate

15 In the process of transferring the SAVAMA inventories into WAAMD, an additional 15 percent of the authors that had not been found, or only partially identified in the field, were identified, usually by the title of their works and their repetition in other WAAMD records.

16 Statistical summaries, here and below, are based on analyses of the first 31 libraries listed in Appendix B.

17 Bruce S. Hall and Charles C. Stewart, "The Historic Core Curriculum and the Book Market in Islamic West Africa," in Graziano Kratli and Ghislaine Lydon (eds.), The Trans-Saharan Book Trade (Leiden: Brill, 2011), 109-174, hereafter "Core Curriculum."

18 Admittedly, this may also bias an analysis of the SAVAMA libraries' contents by comparing them to a "norm" that favors the Islamic sciences over literature reflecting local knowledge practices. 


\section{Figure 1. Mas`ud b. Abi Bakr Library, 53 citations to al-Sanusı̄'s theology.}

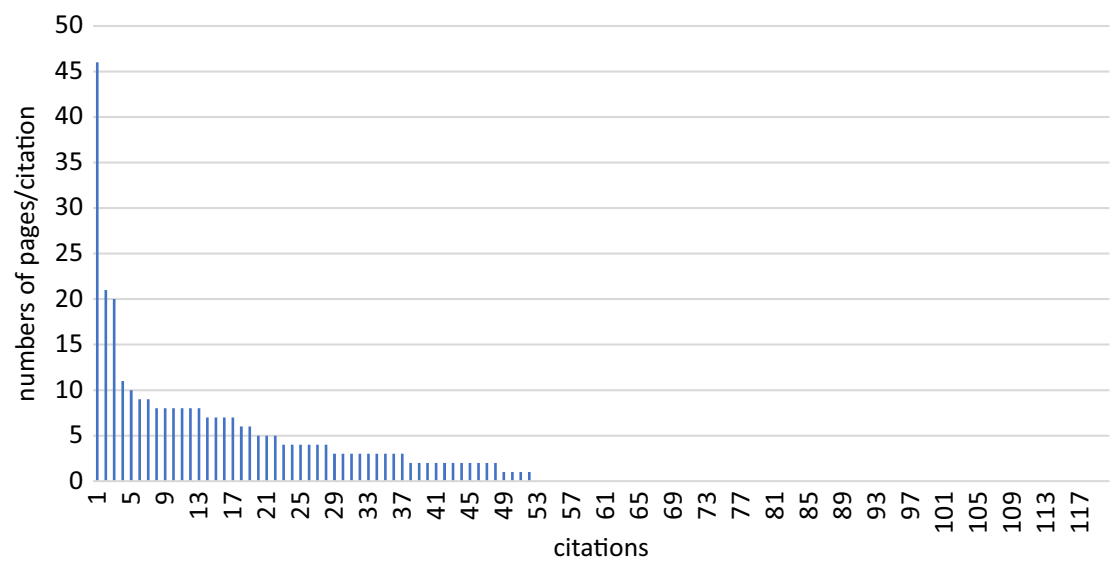

manuscript. For example, Muhammad b. Yūsuf al-Ḥasanī al-Sanūsī’s work on theology, commonly known under the titles 'Aqīdat ahl al-tawhìd al-sughrā and al-Aqüdat al-sughrā and Um al-Barāhaīn, is found in 27 of the 31 SAVAMA libraries. ${ }^{19}$ In them, it is listed 513 times (the three titles also appear at least 111 times elsewhere in the WAAMD database). The length of those complete works in manuscript form in WAAMD records varies, but is always more than fifteen folios. In the 513 SAVAMA citations, only 25 manuscripts meet or exceed that 15-folio threshold. Clearly, fewer than 5 percent of all SAVAMA citations of al-Sanūsī refer to a manuscript that may be his complete work. More than 90 percent of the "copies" of Sanūsī are what I have hypothesized to be "study-sheets," less than 15 folios in length. Figure 1 captures the number of pages per copy of al-Sanūsī's theology found in a single library.

Another example is the famous devotional work on the Prophet by Muhammad b. Sulaymān b. Abī Bakr al-Jazūlī al-Taghtīnī al-Simlālī, Dalā 'il al-khayrāt, cited 521 times in thirty SAVAMA libraries (Figure 2). Fifteen of those 521 records exceed 175 pages, which, judging from the length of copies in WAAMD from elsewhere in West Africa, may be complete or nearly complete works. However, 506 of those citations appear to be fragments of the work, half of them (245) under thirty pages and likely to contain less than 10 percent of the work.

Figure 3 illustrates the number of pages in 43 copies of al-Akhdarī's work on religious duties in a single library.

These exhaustive listings in SAVAMA inventories in which each page of an identifiable work is recorded as a separate manuscript result in some oddly

19 Charles C. Stewart, Arabic Literature of Africa, vol. V: The Writings of Mauritania and the Western Sahara (Leiden: Brill, 2016), 742. 
Figure 2. Abu Bakr b. Sa'id Library, 118 citations to al-Jaz̄ilī's Dalā'il al-khayrāt.

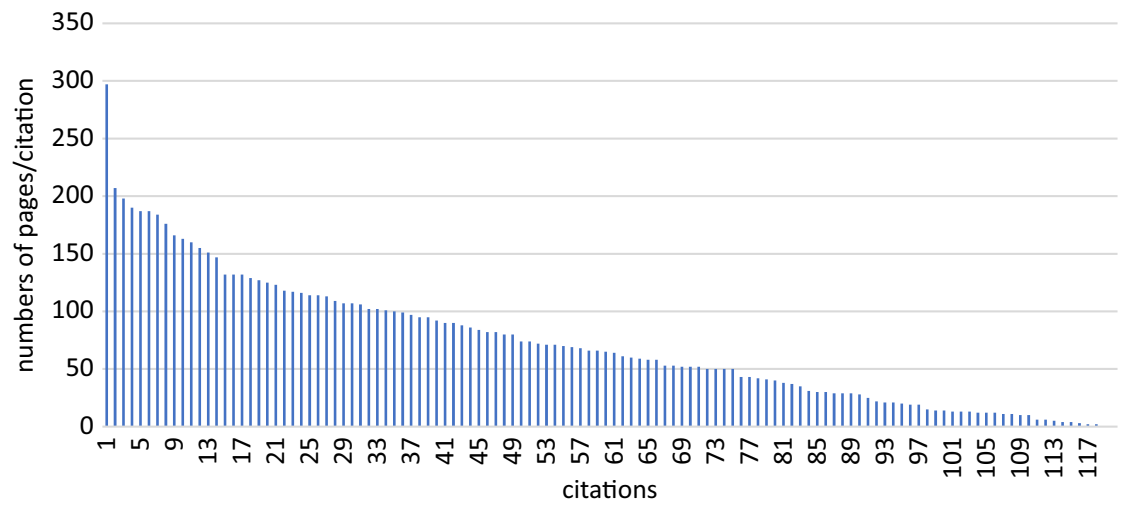

Figure 3. Infa Yatara Library, 43 citations of al-Akhdari’s work on religious duties.

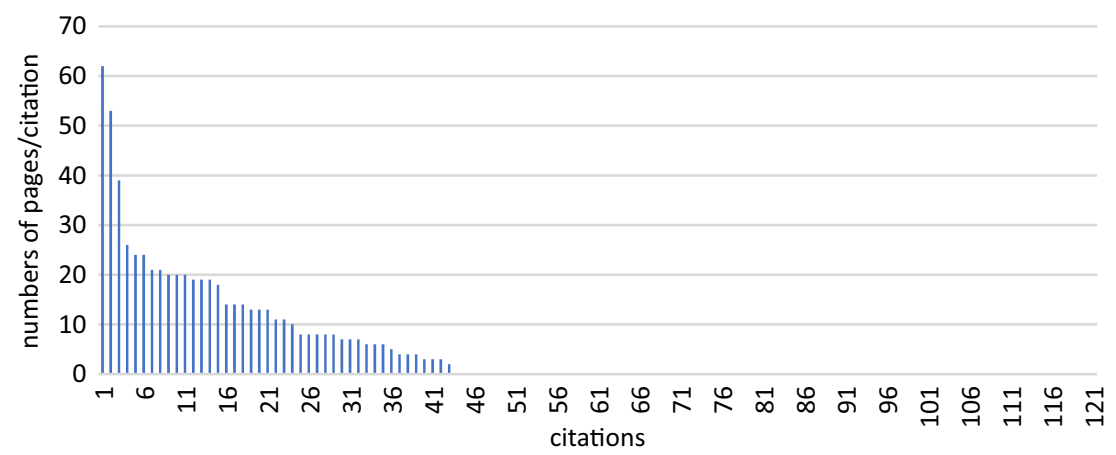

lopsided data on the importance of some authors as well as some very inflated numbers of manuscripts. They also must raise questions about the Hall and Stewart methodology for determining widely studied texts in the absence of page numbers/copies cited. But they do document authors and works that were evidently well studied in twentieth-century Timbuktu. The ratios of the number of "study-sheets" vs. complete works cited here for al-Sanūsī, al-Jazv̄lī, and al-Akhdarī is typical for the frequently cited authors. More than 90 percent of the copies of classical works listed in SAVAMA inventories are, in fact, fragments, many very small fragments, of a work. My hypothesis that the many very brief "manuscripts" in the canon were, in fact, "study sheets" can be tested when digital copies become available. Which segments of works are found on these sheets, as well as the paper on which they are written, will also be revealing, since the availability of inexpensive paper in the twentieth century may explain their profusion. In short, the frequency of an author 
being mentioned in these records in the 31 libraries appears to tell us only that a writer was studied, but it also may indicate his relative importance to scholarship in recent times.

It has been noted that after duplicate names, correspondence, and unidentified partial names are eliminated, the 31 SAVAMA library inventories list just under 180 unique authors; 55 of them are found in at least half of the libraries. Three-quarters of them also appear in the Hall and Stewart "core curriculum." Appendix A summarizes those authors and works that appear in the "Core Curriculum," as well as the authors and works not in the "Core Curriculum" but common to half of the libraries. Interestingly, most of the authors who do not appear in the Hall and Stewart analysis are only found in catalogues dealing with the Niger Bend region and Northern Nigeria. ${ }^{20}$ These seem to include some writers whose names may be conflated with classical authorities or who are also known (and have been inventoried) by local interpolations of their names. The anomaly of their unique appearance in the Segou/Kano/SAVAMA inventories (and nowhere else in West Africa) suggests the need to examine this handful of author attributions more closely.

A correlation between classical authorities represented in the Timbuktu libraries and the "Core Curriculum" found across West Africa might be expected. But on closer inspection, the subject matter emphasized in the SAVAMA inventories does differ in significant ways from writing and teaching reflected in other libraries in WAAMD. Table 1 presents very rough ratios of subjects compared across the "Core Curriculum," SAVAMA libraries (based on 67 of the most frequently cited authors in 31 libraries across 20,000 SAVAMA records), and, for comparison, the original 1991 Timbuktu handlist (all 4,664 records in WAAMD), and the 'Umarian, Segou library (4,138 records in WAAMD inclusive of 1,903 unknown authors).

\section{Comparison of Subject Matter in Select West African Collections}

A careful comparison of these subject classifications, documented by different cataloguers, leads one to understand the wisdom of the decision

${ }^{20}$ That is, they appear in WAAMD records from Segou, Kano, and IHERIAB. It should be noted that the only comprehensive catalogue of any West African collection at the time the Kano records were catalogued and the IHERIAB handlist was prepared was the Segou inventory of al-Hajj 'Umar Tal's library. That work was likely used as a reference in these subsequent cataloguing projects. There are indications the Segou inventory was also used as a reference in the compilation of the SAVAMA material. This may explain some authors and titles in SAVAMA entries, not found elsewhere in WAAMD, that are only found in the Segou collection and Kano. It may also explain why the SAVAMA entries uniformly appear in the same format as found in the Segou catalogue. The 14 authors that share this likely feedback from the Segou inventory into SAVAMA cataloguing have been noted in bold in Appendix A. 
Table 1. Comparison of subject matter in select West African collections.

\begin{tabular}{lcccc}
\hline & $\begin{array}{c}\text { Core } \\
\text { Curriculum }\end{array}$ & $\begin{array}{c}\text { SAVAMA } \\
\text { libraries }\end{array}$ & $\begin{array}{c}\text { Timbuktu (in } \\
\text { WAAMD) }\end{array}$ & Segou library \\
\hline Qur'an & $7 \%$ & $1 \%$ & $4 \%$ & $5 \%$ \\
Arabic Language & $21 \%$ & $4 \%$ & $3 \%$ & $9 \%$ \\
Belief/Theology & $7 \%$ & $23 \%$ & $10 \%$ & $17 \%$ \\
Sufism & $11 \%$ & $8 \%$ & $10 \%$ & $10 \%$ \\
Prophet Muhammad// & $17 \%$ & $19 \%$ & $8 \%+$ devotions & $8 \%+$ devotions \\
$\quad$ Hadith & & & $9 \%$ & $13 \%$ \\
Literature/Poetry & $6 \%$ & $10 \%$ & $15 \%$ & $10 \%$ \\
Jurisprudence & $28 \%$ & $17 \%$ & $29 \%$ & $16 \%$ \\
Conduct/Ethics/ & & $16 \%$ & $3 \%($ ethics) & $4 \%$ (ethics) \\
$\quad \begin{array}{l}\text { Spiritual Counsel } \\
\quad \text { (ethics) }\end{array}$ & & & & $4 \%$ \\
Sciences & $3 \%$ & $3 \%$ & $3 \%$ & $4 \%$ \\
History & nil & nil & $6 \%$ & \\
& & & & \\
\hline
\end{tabular}

in some collections to not try to classify manuscript subjects. There are few immutable rules for the inclusion and exclusion of material in the Islamic disciplines, although Arabic language and Qur'an might be cited as two of the less ambiguous subjects. Even jurisprudence is fungible insofar as a subject like "religious duties" (of outsized importance in the SAVAMA inventories) might be as correctly viewed as part of religious practice (ergo, labeled under "Belief") as a matter of jurisprudence. Thus, the differences between high and low percentages of works on Belief/Theology in the chart above are likely due to the inclusion/ exclusion of writing on religious duties. Writing on the biography, attributes, and characteristics of the Prophet Muhammad is commonly fused in the SAVAMA records with Prophetic love literature (described as "devotional" literature in WAAMD), and sometimes Hadith. The SAVAMA inventories also contain an elevated number of records dealing with conduct and spiritual counsel in comparison to the other collections in this chart. In short, any subject classification system must be approached with caution. ${ }^{21}$ That said, there are remarkable parallels across these collections as well as differences that may reflect variants within West African intellectual history.

One caveat to understanding the historical depth of these libraries: There is no data on the age of manuscripts in the SAVAMA-DCI inventories. A frequent description under "manuscript condition" indicates

21 A word to researchers searching WAAMD for subject matter: searching key words in titles tends to be much more precise than the subject headings. 
"modern script," which suggests writing within the past 50-75 years, but this and the occasional reference to a "very old" work are the only clues to the age of manuscripts. Thus, an important measure of any continuity of today's libraries with Timbuktu's "golden age" in the seventeenth century is missing. That continuity might be implied if we found copies of work that date from that era, but, alas, they are rare. ${ }^{22}$ The near total absence of seventeenth-century writing, the large number of "study sheets" described above, and the inventories all suggest that the SAVAMA libraries, with a very few exceptions, are not ancient, but rather of twentiethcentury provenance. ${ }^{23}$

\section{What are the Distinguishing Features of the SAVAMA-DCI Manuscripts?}

There are several observations that can be made about the subject matter in SAVAMA inventories that do reflect the intellectual baggage in those library holdings. Most striking is apparent confirmation of a note that first appeared in my "Calibrating the Scholarship of Timbuktu." ${ }^{24}$ There, I hypothesized that the near absence of writing on Arabic grammar in seventeenth-century Timbuktu might be explained by a culture in which the teaching of Arabic was monopolized by select scholarly lineages. ${ }^{25}$ The paucity of works on grammar demonstrated by the negligible proportion (only 2 percent) of the content of SAVAMA libraries that include either Ibn Mālik's al-Alfiyya, or Ibn Ājurrūm's alMuqaddima al-ājarn̄miyy $a^{26}$ point to the likelihood that Arabic syntax was still not widely studied in these twentieth-century libraries, or not studied from the

22 Manuscripts attributed to the famous Aḥmad Bāba al-Tinbuktī (d. 1627) appear in two libraries, in each a one-page manuscript, one on the esoteric sciences and the other on religious purification; Muhammad b. Aḥmad b. Mạ̣mūd b. Abī Bakr Baghayogho al-Tīnbuktī's (d. 1655) versification of al-Sanūsī appears in two libraries, one in a one-page and the other an eleven-page manuscript. These are the only four examples of Timbuktu's "Golden Age" among the 20,000 identifiable manuscripts in the 31 SAVAMA inventories.

${ }^{23}$ Based only on the numbers of unique author names in libraries and the presence of nineteenth-century correspondence, seven of the SAVAMA libraries may date from pre-colonial times.

${ }^{24}$ Charles C. Stewart, "Calibrating the scholarship of Timbuktu”, in Toby Green and Benedetta Rossi (eds.), Landscapes, Sources and Intellectual Projects of the West African Past (Leiden: Brill, 2018), 220-238, and Charles C. Stewart, "Évaluer le Niveau de la Culture Savante à Tombouctou," Islam et sociétés au sud du Sahara V (2018), 57-77.

25 Charles C. Stewart, "Calibrating the Scholarship of Timbuktu," 235; this was contrasted, in the same period, with the Mauritanian literature, where manuscripts on grammar made up one third of the writing, and one third of these were commentaries by Mauritanian authors on Mauritanian grammarians.

26 These are the two standard works on syntax found in the Core Curriculum, 157-158; Ibn Malik is cited in only ten of the SAVAMA libraries, and Ibn Ājurrūm is found in 23 libraries. 
classic authorities. Arabic study even in the Golden Age of Timbuktu was likely a subject guarded by a small class of literati; in Goody's description, it was an oligoliterate culture. ${ }^{27}$ Reference below to the widespread presence of preIslamic poets in these libraries suggests the intriguing possibility that applications of Arabic grammar found in early Islamic prosody have supplemented or replaced reliance on classical teaching on syntax. Insofar as al-Harīrī and preIslamic prosody may have served this function, it would argue for a contribution this literature may make to our understanding of the evolution of literacy.

There is no shortage of copies of the Qur'an or sections of the Holy Book in SAVAMA inventories, and the treatment of specific verses and their efficacy in resolving personal problems is a major theme in the esoteric sciences. But at first glance there is a lacuna in the SAVAMA inventories in Qur'anic commentaries/tafsir and recitation/tajwid, although a handful of works identified as Qur'anic knowledge / 'ilm al-Qur'ān may contain such subsets in the discipline of Qur'anic sciences. ${ }^{28}$ The lack of works on recitation, like the relatively few grammars, points to the likelihood that Qur'anic recitation was left to the specialists and was not a widely studied subject. The correct pronunciation of words and styles of recitation have always been a fundamental take-off point in Islamic education, which makes the absence of this subject even more curious in the SAVAMA inventories. The dearth of formal tafsìr/Qur'anic exegesis in some quarters in West Africa has been explained as an artifact of inadequate libraries to research and support interpretation of the Holy Book. ${ }^{29}$ Yet as Bondarev has demonstrated in annotated copies of the Qur'an from early Bornu, a thorough examination of older Qur'anic texts may reveal past access to tafsìrs that are no longer extant in these collections. ${ }^{30}$ Aside from one exegesis by `Abd al-Raḥmān b. Abī Bakr al-Suyūṭ̂, found in two libraries, no other Qur'anic commentaries appear among the most frequently found authors in the SAVAMA inventories. ${ }^{31}$ This may be a genre more frequently found in ‘ajam $\imath$ writing, as Bondarev has

27 Jack Goody and Ian Watt, "The consequences of literacy," Comparative Studies in Society and History 5 no. 3 (Apr. 1963), 313.

28 The only library containing manuscripts on recitation is the al-Ṭāhir Mu'ādh Library, where seven works are found. This deserves further investigation, since the IHERIAB collection contains 41 manuscripts on the subject, signaling that it may simply have not been widely studied/taught in recent times.

29 This explanation comes from the Hassaniyyaphone world where locally authored tafsirs are rare. Bondarev's work on Kanuri texts and 'Abdallahi ibn Fudi's several tafsīrs, especially his Diyā' al-ta'wìl fì ma 'anì 'l-tanzill, suggest differing understandings of Quran'ic exegesis within the region.

30 Dmitry Bondarev, "Tafsīr Sources in Four Annotated Qur'anic Manuscripts from Early Borno," in Zulfiqar Jirji (ed.), Approaches to the Qur'an in sub-Saharan Africa (Oxford: Oxford University Press, 2019).

31 Core Curriculum, 151. The al-Suyuti exegeses are in the Abu Bakr b Sa'id Library (nine copies) and the Almater Mohamed Ibrahim Library (four copies). 
observed and Tal Tamari has described in Bamana texts, but the near absence of classical authorities remains puzzling. ${ }^{32}$ As with the query into the absence of standard grammars above, the source and form of most widely consulted tafsir may not have been the "free-standing" texts devoted to this but rather in marginalia (not well documented in these inventories) or unauthored pages addressing the efficacy of particular sōra in the esoteric sciences.

A second observation from the "Calibrating" analysis, also confirmed by the SAVAMA holdings, is the absence of any indication of obvious tension between local, customary law and the shari'a. Elsewhere in West Africa, this is a barometer for signaling efforts to integrate the shari'a into local usage. Typically, one finds it expressed in "problems" and "answers" in the juridical literature, or commentaries in uss̄l al-fiqh. The SAVAMA inventories are striking for the near absence of this genre of legal writing. Associated with this is also the study of logic, through which skills are acquired to interrogate, parse, and argue legal precedent. Admittedly, the study of logic - where one finds it in the Mauritanian mahazra tradition - went against the grain of Traditionalists, who took pains to avoid the discipline. But it was widespread enough in West Africa that it is unusual that only two of the 31 SAVAMA inventories list any manuscripts on logic (and those sans author and title). ${ }^{33}$

The fact that the SAVAMA inventories include less than half the writing in jurisprudence that is found in other West African libraries is distinctive. One possible explanation, noted above, is that the libraries surveyed here are not "historic" centers of learning with pre-twentieth-century roots. Rather, they reflect twentieth-century scholarship when much of the pre-colonial legal writing had been compromised by colonial administrative law. This is the conclusion I arrived at when comparing two substantial bodies of legal writing in southern Mauritania from the mid-nineteenth and from the midtwentieth centuries in the same village and written by jurists within the same family, three generations apart. ${ }^{34}$ The "bread-and-butter" economic issues from pre-colonial times had largely been replaced 100 years later with fatāwā on religious matters; the well-born and well-connected had evidently found manipulating French legal code, certainly in economic matters, to be more in their interest than rulings according to the sharia. Something like this may explain the dearth of legal literature in these libraries where the principal applications of the shari'a appear to have been in matters defining religious

32 Dmitry Bondarev, "Qur'anic exegesis in African languages," Special Issue of the Journal of Qur'anic Studies 2013, and Tal Tamari', "A Bamana Commentary on Sūrat Al-Wāqia (Q. 56): A Linguistic and Stylistic Analysis,” Journal of Qur'anic Studies 15, no. 3 (2013), 123-183.

33 Nine manuscripts in one SAVAMA library are described as "logic," none with attributed authors.

${ }^{34}$ Charles C. Stewart, "A comparison of the exercise of colonial and precolonial justice in Mauritania,"in Edmond Bernus, et al. (eds.), Nomades et commandants (Paris: Karthala, 1993), 81-86. 
duties, itself a focus for much historic legal writing and studying in West Africa. What is striking, not unlike the dearth of legal writing altogether, is the near total absence of local authorities who authored commentaries, summations, or condensations of legal writing on that one dominant concern: religious duties. Perhaps, as with Qur'anic exegesis, this is where an examination of 'ajami texts will reveal local commentaries and explanations of classical writing.

For libraries that are not strong in the classical literature, it might be surprising to find the near-uniform attention given in two-thirds of these libraries to pre-Islamic poetry and the classic authority on prosody, Qāsim b. 'Alī b. Muhammad al-Harīrī. ${ }^{35}$ Unlike many of the other classic authorities, 75 percent of the al-Harīin manuscripts appear (by their length) to be substantial if not complete texts of his Maqāmāt. Of equal importance are the number of pre-Islamic poets and poets from the early years like Shanfara 'Amr b. Mālik al-Azdī, ${ }^{36}$ Zuhayr b. Ab̄i Sulama al-Muzan̄̄, ${ }^{37}$ Muhammad b. al-Ḥasan b. Durayd al-Azdī, ${ }^{38}$ Imru' al-Qays b. Ḥujr b. al-Ḥārith al-Kindī , ${ }^{39}$ and Hasan b. 'Alī al-Ișfahān̄̄ al-Ṭughrā's. ${ }^{40}$ Their significance lies in the likelihood that they provided the method and template for adapting Arabic script to poetry in African languages and/or adapting poetry in African languages to classical Arabic forms. It may also provide a clue to an application of these texts for the study of grammar in lieu of classical texts. This relation between al-Harīrī, the pre-Islamic poets, and templates for ‘ajami writing awaits research, but something similar is found in Hassaniyya poetry, and Tal Tamari has described the influence of al- Harīrī on Bambara prosody. ${ }^{41}$ A similar methodology may be anticipated in adapting Arabic to other African languages, and, if demonstrated, the strong presence of these authorities across these libraries suggests their importance in fostering ajami writing. The WAAMD records indicate 213 documents in ajam SAVAMA inventories, which does not include the large number of short items that are only available on their original spreadsheets in WAAMD. Nor is it

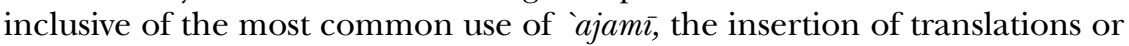
explanations of Arabic words in the marginalia of texts. Ajamı is found in about 11 percent of the SAVAMA entries in WAAMD; across all WAAMD records, ‘ajami ranges between $10-15$ percent. ${ }^{42}$ The field of “ajami studies

35 Core Curriculum, 159, (found in 22 SAVAMA libraries in 104 citations).

36 Core Curriculum, 160, (in 19 libraries, 57 citations).

37 Core Curriculum, 161, (in 18 libraries, 43 citations).

38 Core Curriculum, 157, 161 (in 24 libraries, 92 citations).

39 Core Curriculum, 160, (in 16 libraries, 34 citations).

40 Core Curriculum, 160, (in 12 libraries, 32 citations).

41 Tal Tamari, "La prose littéraire arab en traduction Bambara: une maqama d'al-Hariri," in Ursula Baumgardt and Jean Derive (eds.), Paroles nomads. Ecrits d'ethnolinguistique en homage à Christiane Seydou (Paris: Karthala, 2005), 431-463.

42 The al-Ṭāhir Mu'ādh Library and Abu Bakr b. Sa'id Library together account for well over half of the references to ‘ajami texts in the SAVAMA libraries, perhaps an 
and the notion of the "ajamization of Islam" in West Africa is relatively new, recently summarized by Fallou Ngom. ${ }^{43}$ At Hamburg's CSMS, Dmitry Bondarev is directing a long-term project focused on documenting and exploring ajami materials in the SAVAMA-DCI manuscripts reviewed here.

The SAVAMA-DCI inventories contain more correspondence than any other collection in WAAMD. Over 7,000 letters provide insight into quotidian affairs, from social relations and commerce to legal opinions. ${ }^{44}$ The two most frequently cited subjects are social greetings and commercial affairs; if, as suggested above, these libraries represent mainly twentieth-century holdings, bodies of this correspondence should offer a unique vantage point on colonial occupation and the colonial economy from the point of view of the literati. Individual libraries tend to be dominated by their custodians' correspondence (or their custodians' forebearers letters), but names of particularly prolific letter writers reappear across libraries often enough to track the affairs of a few of the correspondents. The much larger number of letter writers than scholars, evident in this sampling, invites inquiry into the training for letter writing supported by these libraries that, as the volume of letters suggests, must have been an important teaching subject. ${ }^{45}$

The relatively heavy concentration of texts on Belief/tawhid in SAVAMA inventories deserves comment. This one body of writing not only features more of the "Core Curriculum" texts than any other category, but when joined with devotional material accounts for three-quarters of all the texts that are new to the "Core Curriculum" compilation. If there is a center to the Islamic culture in this Timbuktu literature it would be this - theology and spiritual instruction - and that contrasts with typical foci (that vary) in other WAAMD libraries on jurisprudence, language and literature, and the Prophet Muhammad. Why this should be the case, or if this may be a misreading of the SAVAMA inventories, will be solved by future research. Certainly, these inventories do not contain the quantity and depth of praise literature and poetry typically found in other Saharan libraries, although this may be revealed in 'ajam $\bar{\imath}$ writing, and they are rich in Prophetic love literature. The intellectual ingenuity on display here is not to be found in the study, commentaries, and adaptations of classical Islamic texts but rather in adaptations of the Arabic script to African languages in ‘ajami writing.

artifact of cataloguing protocols used in those collections. WAAMD notes the presence of "ajami script in the subject field for an entire work or in the "miscellaneous" field where it appears as commentary/explanation of Arabic words.

${ }^{43}$ See Fallou Ngom and Mustapha Kurfi (eds.), Ajamization of Islam in Africa, Special Issue of Islamic Africa 8 no. 1-2, (October 2017).

44 Over half of these are in the Mouhamad Sidik Library, not yet entered in WAAMD, mainly dealing with commercial matters.

45 The work most widely found across West Africa on letter writing by 'Umar b. Abī Bakr b. 'Uthmān al-Kabawī al-Ṣalghawī al-Kanawī is found in 12 SAVAMA libraries in 38 copies. 
The dominant genre in the SAVAMA-DCI libraries presents a special challenge to bibliographers: the tens of thousands of short, one- and twopage items without authors, with attributed titles, and with subject matter that often specifies the affect or the efficacy of the text. This also presents one of the greatest challenges to utilizing most of the documents in these inventories. These one- and two-page items make up 75 percent of all SAVAMA inventories. At least one-quarter of all these records describe their subject matter with the terms: fawā'id (beneficial), or al-manaf'a (of benefit), or as fadā'il (of virtue), or al-khawās (special value). These are frequently items in the esoteric sciences, and their attributed titles indicate they deal with a specific sīra, discrete branches of the esoteric sciences, specific types of devotions, conduct, ethics, or elements of belief (names of God, names of saints, etc.). For records exceeding two pages identified in this way that have been entered in WAAMD, where key words in titles made more precise content identification possible, those topics have been identified as subjects. But this has also corrupted those qualitative subject designations entered in the field. For these, students will need to consult the original subject designation assigned in the field, available on the library inventory spreadsheets at the CSMC/SAVAMA site and, for the one- and two-page items lacking authorship, at the link on WAAMD collections pages. Paul Naylor has argued that these items might best be categorized by the qualitative value assigned by cataloguers in the field. ${ }^{46}$ There may be a typology for their categorization waiting to be formulated, based on the intersection of the texts of origin and the social context in which they found application. A team at the Hill Museum and Manuscript Library is currently working on such a system of categorization of these items that will hopefully make them more accessible than they are at present.

\section{Conclusion}

The SAVAMA-DCI inventories give us the first near-comprehensive inventory of a West African manuscript culture within a circumscribed site. That the site is Timbuktu is bound to add luster to any findings, but it is, in fact, probably also typical of many urban, Islamic cultures in the twentieth century where multiple private libraries are found or have been amalgamated. The SAVAMA-DCI libraries provide a unique opening to the intellectual makeup of Islamic Africa in the twentieth century. It is therefore more profound and complicated than earlier assumptions about a seventeenthcentury scholarship still alive 300 years later in the fabled manuscripts of Timbuktu. Clearly, most of these are not libraries of any great historical

46 Paul Naylor, "West African Esoteric Material (Fawā' $i d)$ : identification, content and cataloging strategy" presentation at the workshop, Working with Arabic-script Manuscripts in Africa, Northwestern University, August 15, 2017. 
depth, nor do they contain much extended writing in the Islamic disciplines by local authors.

These libraries document well the fact that Timbuktu was not the center of West African Islamic scholarship that popular belief has wanted it to be. The paucity of Arabic language texts suggests an oligoliterate culture, and the absence of subjects like logic suggest legal reasoning was not a part of the limited juridical writing. Further, the lack of evidence of tension between customary law and the shari'a implies not an Islamic culture that rested on jurisprudence, but rather one where the overwhelming juridical preoccupation was with religious duties. ${ }^{47}$ The profusion of Prophetic love literature appears to largely define this Islamic culture and is without a parallel in other WAAMD libraries. If a manuscript library can reveal the teaching and learning most valued in an Islamic culture, we must look outside the classical canon in the Islamic sciences to find the value of these manuscripts of Timbuktu. Despite the claim in much of the hype about the Timbuktu manuscripts that they are an embodiment of classical Islamic learning dating back to the sixteenth century, this is not reflected in the contents of these libraries.

What is reflected in the contents of these libraries is something far more complex and much more interesting. What the SAVAMA inventories tell us is that the importance of Timbuktu's manuscript culture needs to be assessed in its own terms. This can begin by taking seriously the vast corpus of one- and two-page, largely twentieth-century formulas. This genre grew, in part, out of sources drawn from the classical disciplines, no doubt married to local needs. The modest number of classical sources evidenced today in these libraries ought to make the mapping of their classical roots relatively easy. This is a body of literature that may be an artifact of the relative ease of access to paper in the early twentieth century. It also suggests that inexpensive paper may have also ushered in a new way of learning in a post-lauh age, as well as explaining the "study sheets" noted above. $^{48}$

Perhaps most significant is the evidence of al-Harīin and the pre and early Islamic poets across these libraries and the possible link between that literature and adaptations of classical meter to 'ajami verse. In brief: This body of literature opens questions and calls for a new thinking about the intellectual history of Timbuktu, not constrained by an Islamic canon but innovative and original in its applications of an Arabic literary past to the formulations of an African literature in Arabic script.

47 Most legal cultures throughout the world focus on inheritance, marriage, and divorce; these are only nominal themes in the SAVAMA literature.

48 The lauh or wooden copy board on which lessons were written until memorized, found across West Africa in the nineteenth century. 


\section{Appendix A}

Core Curriculum authors/works and their frequency in SAVAMA libraries. Bold entries indicate 23 authors not present in the Core Curriculum, but found in at least three-quarters of SAVAMA libraries. ${ }^{49}$

\section{Qur'anic Sciences}

- Recitation (tajwīd)

- Ibn al-Barrī, al-Durar al-lawāmi ${ }^{50}$

- Ibn Jazarī, al-Muqaddima al-jazariyya ${ }^{51}$

- Qur'anic revelation (tanzīl) and abrogation (naskh)

○ Ibn Juzaī, al-Tashīl li- ul̄̄m al-tanzi $\bar{\imath}^{52}$

- Exegesis (tafsirr)

○ al-Suyūṭī and al-Maḥalīli, Tafsīr al-Jalālayn ${ }^{53}$

\section{Arabic Language}

- Lexicons and Lexicology

- Muhammad b. al-Mustanīr Quțub, Muthallath Qutrub ${ }^{54}$

- ‘Abd al-`Azīz b. `Abd al-Waḥīd al-Lamțī al-Miknasī, Sharh al-Mōrith Qutrub ${ }^{55}$

- Morphology

○ Ibn Mālik, Lāmiyyat al-af ā $l^{56}$

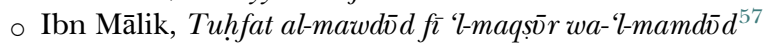

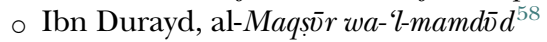

49 Fourteen of these have not been found in other West African libraries, but can be traced to the Segou catalogue: Ghali, Mahibou and Brenner, Inventaire de la Bibliothèque 'Umarienne de Segou (CNRS, 1985); see note 19, above.

50 Core Curriculum, 154. Only two commentaries of this classic are listed, in only two SAVAMA libraries, one 12 pages in length and the other two pages; this is the most wide-spread work on Imam Nafi' that is found in 74 WAAMD records, usually in the form of commentaries on his original work.

In the following notes the word "citations" may refer to the complete work or, most frequently, to an extract that may be as little as one or two pages in length (see above discussion of "study sheets" and see WAAMD records for details).

51 Core Curriculum, 155, 12 citations in four libraries.

52 Core Curriculum, 155, two manuscripts of 256 and 240 pages in the Cheikh Ibrahim Alhassan Library

53 Core Curriculum, 155, four citations in three libraries.

54 Core Curriculum, 156, known in West African sources as "Qutrub b. Ahmad," found in 14 SAVAMA libraries, 28 citations.

${ }_{55}$ Core Curriculum, 156, one and two-page fragments are found in five libraries.

56 Core Curriculum, 156, seven fragments, only one of which exceeds eight pages.

57 Core Curriculum, 157, 17 citations found in nine libraries

58 Core Curriculum, 157, 85 citations found in 26 libraries. 
- Syntax

○ Ibn Mālik, al-Afiyya ${ }^{59}$

○ Ibn Ājurrūm, al-Muqaddima al-ājarrōmiyya ${ }^{60}$

- Rhetoric

- 'Abd al-Raḥmān b. Muhammad al-Akhdarī, al-Jawhar al-makn̄̄ $n^{61}$

- Literature/Prosody

- Qāsim b. 'Alī b. Muhammad al-Harīīī, al-Maqāmāt li-'l-Harīn̄í2

Shanfara `Amr b. Mālik al-Azdī, Lāmiyyat al- $a r a b^{63}$

- Ḥasan b. `Alī al-Iṣfahānī al-Ṭughrā'î, Làmiyyat al-`ajam ${ }^{64}$

- Ibn Durayd, al-Maqș̄ona ${ }^{65}$

○ Imru' al-Qays b. Hujr b. al-Ḥārith al-Kindī, Bānat su 'ā $d^{66}$

\section{Prophet Muhammad}

- Biography (sira)

- ‘Abd al-`Azīz b. `Abd al-Waḥīd al-Lamțī al-Miknasī, Qurrat al-abșār ${ }^{67}$

- Devotional Poetry

○ Mughaltāy b. Qilīj b. `Abd Allāh al-Bakjarī al-Ḥikrī al-Ḥanafî, Khașā ’ị al-muștafā ${ }^{68}$

- Muḥammad b. Sa īd al-Būṣīnī al-Ṣanhājī, and Muhammad b. `Abd al-Raḥmān al-Marrākushī (sic), al-Burda [al-Kawākib al-durriyya... $]^{69}$

59 Core Curriculum, 157. Found in nine SAVAMA libraries; 24 citations of manuscripts ranging from two to 111 pages; in addition, there are two citations to al-Suyuti's commentary and two citations to al-Ushmūnī's commentary.

${ }^{60}$ Core Curriculum, 158. Found in 23 SAVAMA libraries; 65 citations.

61 Core Curriculum, 159. Found in three SAVAMA libraries; in one, seven and 12-page fragments.

62 Core Curriculum, 159. Found in 22 SAVAMA libraries; 104 citations.

63 Core Curriculum, 160. Found in 19 SAVAMA libraries; 57 citations.

${ }^{64}$ Core Curriculum, 160. Found in 12 SAVAMA libraries; 32 citations.

${ }^{65}$ Core Curriculum, 161. Found in 24 SAVAMA libraries; 94 citations.

${ }^{66}$ Core Curriculum, 161. Found in 16 SAVAMA libraries; 34 citations.

67 Al-Miknasī is a Core Curriculum authority in lexicology (found in 3 SAVAMA libraries), but it is his work on the names of the Prophet that is most wide-spread in the SAVAMA inventories, found in 27 citations in 14 libraries.

68 Core Curriculum, 161. Found in 16 SAVAMA libraries; 40 citations.

69 This title is usually attributed to Muhammad b. Sa `̄ì al-Būṣīrī al-Ṣanhājī (Core Curriculum, 162) but it appears over 296 times in the SAVAMA inventories, where it is also attributed to several other authors including Muhammad b. `Abd al-Raḥmān al-Marrākushī, mentioned here, and Muhammad al-Badamāṣī (two authors who are found in WAAMD records only in the Segou and the SAVAMA inventories, suggesting the likely dependence on the Segou catalogue as a reference for the Timbuktu project). In other SAVAMA records the title is attributed to Muhammad b. Yūsuf al-Ḥasanī al-Sanūsīi al-Ḥasan b. Mašūd al-Yūsī al-Marrākushī, and even Ibn Abī Zayd al-Qayrawānī. 
○ 'Abd al-Rahman b. Yakhlaftān b. Ahmad al-Fāzāzī, al-'Yshrīnīyāt $t^{70}$

- Muḥammad b. Sulaymān b. Abī Bakr al-Jazūlī al-Taghtīnī al-Simlālī, Dalāil al-khayrāt ${ }^{71}$

○ Muḥammad b. ‘Abd Allāh b. Sa ād al-Fūtī, Qasìida fì madh al-nabī72

- Ibn Naḥwī: Abū al-Faḍl Yusuf b. al-Naḥwī al-Tawzari, Qașìda al-munfarija ${ }^{73}$

- Muḥammad b. Aḥmad b. Marzūq al-Tilimsānī, al-Qașìda al-marzūqiyya ${ }^{74}$

- Muḥammad b. `Abd al-`Azīz b. al-Warrāq al-Iskandarī, and Muḥammad b. `Abd al-`Azīz al-Lakhmī, Qașìda al-watariyya ${ }^{75}$

- Zuhayr b. Abī Sulama al-Muzanī, Bānat su āa ${ }^{76}$

- 'Umar b. Sa `̄ìd b. 'Uthmān b. al-Mukhtār al-Fūtī, Kasb al-faqīir 77

- Muḥammad b. Muhammad b. Aḥmad al-Ghazālī, al-Kanz al-a żām and Salāt al-kaymaya ${ }^{, 78}$

○ 'Uthmān b. Muhạmmad Fūdī, Mukht̄̄o al-șalāt ‘ala al-nabì ${ }^{79}$

\section{Hadith collections}

○ Muhạmmad b. Ismā`̄il b. Ibrāhīm al-Bukhārī, Șahịh al-Bukhārī ${ }^{80}$

- Ibn al-Jazari, Hiṣn al-hașin ${ }^{81}$

- Sciences of Hadith

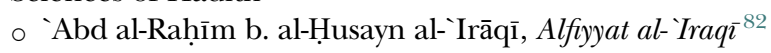

${ }^{70}$ Core Curriculum, 162. Found in 18 libraries in 26 citations, plus 28 commentaries by Ibn Mahib (Core Curriculum, 162).

71 Core Curriculum, 162. Found in 26 libraries in 522 citations.

72 This author is unique to the SAVAMA inventories, not found elsewhere in WAAMD; found in 16 libraries; 32 citations.

73 Core Curriculum, 163. Found in 22 libraries in 54 citations.

74 Found in 27 copies in 14 SAVAMA libraries; one copy in IHERIAB. This author appears in the Core Curriculum for his derivative text on Khalil (Core Curriculum, 166) but not for this devotional poem.

75 The titles attributed to these two 'Muhammad b. 'Abd al-'Aziz' authors are the same, suggesting they may be different versions of the same name; the names appear in 22 libraries, in 68 citations.

${ }^{76}$ Core Curriculum, 161; 55 citations found in twenty libraries.

77 This title appears once in the Segou catalogue, under another author, and with al-Hajj 'Umar as author 59 times in 23 SAVAMA libraries.

78 Among several attributed titles given to al-Ghazali in the SAVAMA libraries, these are the most frequent. Of the two works by al-Ghazali cited in the section on Belief in the Core Curriculum, 170, one of them, Tarjid fi kalimat al-tawhìd, does appear in a two-page copy in the Infa Yatara Library.

79 Dan Fodio is cited in the Core Curriculum, but not for his writing in devotions. Found in 19 libraries; 43 citations; among the other widely found devotional writings by dan Fodio are: $D \bar{v} \bar{a}^{\prime}$ al-al-sv̄fi (13 copies); Takhmīs qașìda Banat su'ād (three citations); and five other titles that need confirmation.

${ }^{80}$ Core Curriculum, 163. Found in six libraries in thirty citations.

81 Core Curriculum, 163. Found in four libraries in 12 citations.

82 Core Curriculum, 164. Found in a single copy of 48 pages. In the Cheikh Ibrahim Alhassan Library. 


\section{Jurisprudence $(f i q h)$}

- Ușv̄l al-fiqh

○ Tāj al-Dīn `Abd al-Wahhāb b. `Alī al-Subkī, Jam `al-jawāmī fì ‘l-ușv̄ $l^{83}$

- Furv̄' al-fiqh: Foundational texts

○ Mālik b. Anas al-Așbahī, al-Muwatta ${ }^{84}$

- Sulaymān b. Khalaf b. Sa `d al-Bājī, al-Muntaqā sharh al-muwatta, ${ }^{85}$

- Khalaf b. Abī al-Qāsim Muhammad al-Barādhi`ī, Tahdhìb masā' il al-mudawwana ${ }^{86}$

- Furv̄' al-fiqh: Fiqh manuals

○ Ibn Abī Zayd al-Qayrawānī, al-Risāla ${ }^{87}$

- 'Alī b. Muḥammad al-Manūfĩ al-Shādhilī, Kifāyat al-tālib al-rabbānī li-'l-Risāla ${ }^{88}$

o Khalīl b. Isḥāq al-Mālikī al-Mișrī, Mukhtașar Khalīl ${ }^{89}$

- Muḥammad b. Ibrāhīm b. Khalīl al-Tatā'̄̄, Jawāhir al-durar ${ }^{90}$

- 'Abd al-Bāqi b. Yusuf al-Zurqānī, Sharh mukhtasar Khalīl ${ }^{91}$

- Muhammad b. al-Ḥasan al-Bannānī al-Fāsī, Fatḥ al-rabbānī fì mā dhahala `an-hu al-Zurqān $\imath^{-92}$

- Muhammad b. `Abd Allāh al-Kharshī al-Mālikī al-Mișrī, Sharh `alā 'l-Mukhtașar Khalil $^{93}$

- Ibn `Āṣim al-Gharnāțī, Tuḥfat al-hukkām fì nakt wa-'l-ahkāa m ${ }^{94}$

- Muḥammad b. Aḥmad b. Muḥammad al-Mālikī al-Fāsī, al-Tanqāt wa'-l$a h k \bar{a} m^{95}$

- Ibn `Askar al-Baghdādī, Irshād al-sālik ilā ashraf al-masālik ${ }^{96}$

- `Alī b. Muhammad al-Manūfī al-Shādhilī, al-Muqaddima al-'izziya li-l-jamā’a al-azhariyy $a^{9 \dot{7}}$

83 Core Curriculum, 164. Found in six libraries in six citations.

${ }^{84}$ Core Curriculum, 165. Found in eight libraries in 16 citations.

85 Core Curriculum, 165. Found in 14 libraries in 36 citations.

86 Core Curriculum, 166. Found in the Abu Bakr b. Sa'id Library; one manuscript of 174 pages. This is a commentary on Sahnun (not found in the SAVAMA libraries).

87 Core Curriculum, 167. Found in 29 libraries in 320 citations.

88 Core Curriculum, 166. Found in four libraries in four citations.

89 Core Curriculum, 167. Found in 18 libraries in 73 citations.

90 Core Curriculum, 167. Found in the Abu Bakr b. Sa'id Library in two copies, 260 and 207 pages.

91 Core Curriculum, 167. Found in two libraries in a one-page extract and a 136-page manuscript.

92 Core Curriculum, 167. Found in the Abu Bakr b. Sa'id Library in a manuscript of 207 pages.

93 Core Curriculum, 167. Found in three libraries in six citations.

94 Core Curriculum, 167. Found in 17 libraries in 76 citations.

95 Core Curriculum, 167. Found in two libraries in two citations, 41 and 347 pages.

${ }^{96}$ Core Curriculum, 168. Found in 17 libraries in 55 citations.

97 Core Curriculum, 168. Found in 25 libraries in 106 citations. 
○ ‘Alī b. Aḥmad b. Sa ìd b. Ḥāzim al-Andalusīi, Kitāb al-Ṣalāt and Du 'ã’ miḥan al-rufāt ${ }^{98}$

- Didactic texts

○ 'Abd al-Raḥmān b. Muhammad al-Akhdarī al-Th ālbī al-Jazā’irī, Mukhtașar fi 'libā $d \bar{a} t^{99}$

- Muḥammad b. Aḥmad b. 'Uthmān al-Mazmarī, al-'Abqarī fì naẓm sahw al-Akhdari ${ }^{-100}$

○ 'Abd al-Bārī al-Rifā’ī al-'Ashmāwī, al-Muqaddima al- 'ashmāwiyya ${ }^{101}$

- Al-Qawā'id al-fiqiyya

○ Ibn Juzay al-Gharnāṭ̂̄, Qawānin al-ahkāam $m^{102}$

\section{Belief (tawhid)}

- Aḥmad b. ‘Abd Allāh al-Jazā'irī, Manž̄ōmat al-Jazā 'iriyya fì 'l-tawhī $d^{103}$

○ Khālid b. Yaḥyā b. Yōsuf al-Jaz̄̄lī, Natīja al-ilhām fì waşf dar al-Istā $m^{104}$

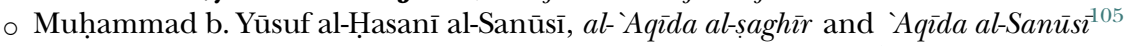

- Muḥammad b. `Abd al-Raḥmān b. `Alī al-Hawḍ̂̄, Wāsita al-sālūk k106

- Muḥammad b. Abū Bakr b. Muḥammad Baghayogho, Nazm șaghīrì al-Sanūsît 107

- Yahyya b. ‘Umar al-Qurțubī al-Azdi, Urjūza al-waladān $n^{108}$

- Nașr b. Muḥammad b. Aḥmad al-Samarqandī, Tanbìh al-ghāfilīn ${ }^{109}$

98 This author is unique to Timbuktu; he appears in one IHERIAB record and in 17 SAVAMA libraries where there are 31 citations. There may be confusion here between the eleventh-century Andalusian scholar, known as Ibn Hāzim (994-1064), none of whose known writings appear in the SAVAMA project, and another author in WAAMD known as Hārith Ab̄̄ al-Hāzim, whose writings are similar to those attributed to this author in the SAVAMA inventories.

99 Core Curriculum, 168. Found in 25 libraries in 425 citations.

100 This author is cited among the literature/prosody authorities in the Core Curriculum; here he is cited 50 times in 21 libraries for his commentary on al-Akhdarī; this title is attributed to other authors in WAAMD and only in the Segou and SAVAMA records to al-Mazmarī.

101 Core Curriculum, 168. Found in 28 libraries in 212 citations.

102 Core Curriculum, 169. Found in one six-page extract in one library.

103 Core Curriculum, 171. Found in 25 libraries in 149 citations.

104 This title is found in 20 SAVAMA libraries in 90 citations, most attributed to al-Jazōlī, but also Khālid b. Yahyā al-Jarsifī (13 citations), Muhamamad b. Yūsuf al-`Abdarī al-Gharnāṭi , and six citations in the Mohamed Ould Ousmane Library to Muḥammad Ḥabīb Allāh [Ḥabībaḷ̂ā] b. Māyāba al-Yūsufî al-Jakanī.

105 Core Curriculum, 170. Found in 27 libraries in 516 citations.

106 Core Curriculum, 170. Found in one library in a two-page extract.

107 Core Curriculum, 170. Found in three libraries in four citations, two onepage copies, a six page and 11-page copy.

108 Core Curriculum, 170. Found in 22 libraries in 392 citations. This title is only found in records from Segou and the SAVAMA libraries where the author is known as Abū Bakr Yahya b. 'Umar b. Sa dūn al-Qurțubī. In the Kano records the work is entitled: Manẓ̌̄ma al-Qurțubī fì al-`ibādāt

109 Core Curriculum, 170. Found in nine libraries in 21 citations. 
- Aḥmad b. `Abd Allāh al-Jazā’irī, al-Manzūma al-jazā 'riyya fì al-tawhī $d^{110}$

- Ibrāhīm b. Ibrāhīm b. Ḥasan al-Lāqanī, Jawahir al-tawhì $d^{111}$

- Aḥmad b. Muḥammad al-Maqqarī al-Tilimsānī, Ida'āt al-ḍjunna fì ‘aqā'id ahl al-sunna ${ }^{112}$

- Muḥammad b. al-Mukhtār b. al-A`mash al-`Alawī, Futūhāàt dhī al-raḥma fì sharh ida'at al-dujunna fì al-Maqqari ${ }^{-113}$

- Arbāb al-Kharțūmī: Arbāb b. `Alī b. `Āwn b. `Amir b. Așbah al-Kharțūmī, al-Jawāhir al-ḥisān fi taḥqùq ma'rifat arkān al-imā $n^{114}$

- ‘Abd al-Wāḥid b. Aḥmad b. `Alī b. `Āshir al-Anșārī al-Fasī, al-Murshid al-mu ìn `alā 'ldarūrū min ulūm al-dìn ${ }^{115}$

- Muḥammad al-Ṣāliḥ b. 'Abd al-Raḥmān al-Awjalī, Dalīl al-qā'id li-kashf asrār sifāt al-wāhid ${ }^{116}$

Muhạmmad b. al-Ḥasan al-Shaybān̄̄, 'Aqūda al-Shaybān $\bar{\imath}^{117}$

'Abd al-Raḥmān b. Aḥmad al-Waghlīsī, al-Muqaddima al-Waghlīsīi ${ }^{118}$

Muhammad al-Ṭughūghī b. Muḥammad Inālbush al-Sūq̄î, Nazm `aqìda sūra al-ikhlās and Shāfiyya al-qalū $b^{119}$

- Abū 'Imrān al-Jurādī, Kitāb fi tawḥī $d^{120}$

Abō `Abd Allāh Muhammad b. `Úmar, al-Bida` al-shaytānniyya ${ }^{121}$

Muhammad b. 'Uthmān b. Aḥmad al-Baghūnī al-Awsī (Aūsī), Bada' al-āmā $\bar{\imath}^{123}$

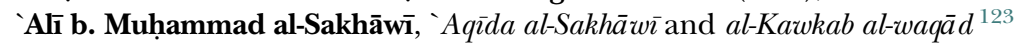

110 Core Curriculum, 171. Found in 25 libraries in 112 citations.

111 Core Curriculum, 171. Found in nine libraries in 14 citations.

112 Core Curriculum, 171. Found in 17 libraries in 38 citations.

113 Core Curriculum, 171. Found in two libraries in copies of two pages and manuscript of 97 pages.

114 Core Curriculum, 171. Found in 19 libraries in 55 citations.

115 Core Curriculum, 171. Found in 21 libraries in 71 citations.

116 Core Curriculum, 172. Found in 17 libraries in 100 citations.

117 Found in 25 libraries in 130 citations; additional citations to this author and work are found in Kano and Segou records.

118 Found in 12 libraries in 24 citations; this author is also found in the Segou records but not elsewhere in WAAMD.

119 Found in 11 libraries in 17 citations; this author is also found in WAAMD in the Segou, Kano, Niamey and Timbuktu IHERIAB records.

${ }^{120}$ Found in four libraries in seven citations; this author is also found in WAAMD in the Segou and Timbuktu IHERIAB records.

121 Found in 11 libraries in 27 citations; this author is unique to SAVAMA inventories; the title, however, is one found widely in WAAMD where it is attributed to `Uthmān b. Muhammad Fūdī.

122 Found in seven libraries in nine citations; this author is also found in Segou records but not elsewhere in WAAMD.

123 Found in 24 libraries in 79 citations; this author is also found in Timbuktu IHERIAB, Segou and Nouakchott. 


\section{Devotional and spiritual counsel, esoteric sciences, other}

- Muhammad b. Aḥmad b. Marzūq al-Tilimsānī, Qasīda al-munfarija ${ }^{124}$

- Abū Madyan Shu ayb b. al-Ḥusayn al-Anșārī al-Tilimsān̄̄, Maqșūra al-jawahir and Istighfār Abu Maydan ${ }^{125}$

- Wahhab b. al-Wardī, Kitāb fĩ al- mawā iż. ${ }^{126}$

- Muhammad al-Wālī b. Sulaymān al-Fulānī al-Bāghirmāwī al-Barnāwī, Manhal mā' al- athb li- ilm asrār șafāt al-rabb ${ }^{127}$

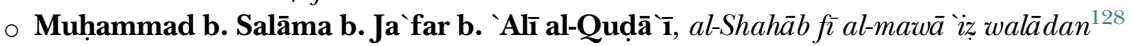

- Bad b. al-Faqih Sanba b. Buḍ al-Fulānī, Manž̄ma fì al-mawā iz and Qașìda Banat su'ā $d^{129}$

- Aḥmad b. Muhammad al-Zarnūjī, Ta lìm al-muta allim li-tarì al-ta 'llum ${ }^{130}$

- Ibrāhīm b. Mas `ūd b. Sa īd al-Ilibīīī, Qasìda tā 'iyya ${ }^{131}$

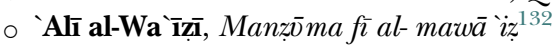

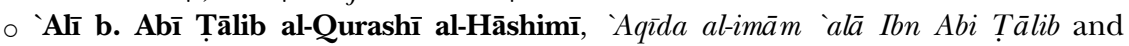

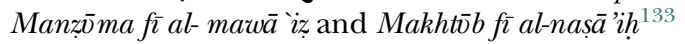

○ Aḥmad al-Bakkā̄ī b. Sīdī Muḥammad Sidi al-Mukhtar al-Kuntī, Qasīda fì tawassul and al- Qasīda al-ma iñfiyya ${ }^{134}$

- Sĩdi Muḥammad b. Sĩdi al-Mukhtār al-Kuntī, various ${ }^{135}$

o Sīdi al-Mukhtār b. Aḥmad b. Abī Bakr al-Kuntī, various ${ }^{136}$

124 This author appears in the Core Curriculum for his commentary on Khalil's legal manual but is best known in SAVAMA libraries for this devotional work where 34 citations are found in 16 libraries.

125 Found in 27 libraries in 224 citations: also, in Kano, Segou, Nouakchott.

126 Found in 17 libraries in 124 citations; this author also appears in Kano and Segou records, and may be confused with the grammarian known (also) as Ibn al-Wardī, who is found in the Timbuktu IHERIAB collection and two SAVAMA libraries.

127 This author is in the Core Curriculum (170) but for a different title; this title is unique to the SAVAMA inventories where it is cited nine times in six libraries.

128 Found in 14 libraries in 30 citations: also, in Kano and Niamey.

129 Found in 13 libraries in 30 copies; this author is unique to the SAVAMA inventories.

${ }^{130}$ Found in 18 libraries in 70 citations; this author and title also appears in Segou, and Kano records.

131 Found in 11 libraries in 31 citations; this author is also found in Kano records.

132 Found in 25 libraries in 136 citations; this author, also known as Abū al-Hasan

'Alī, and title are unique to the SAVAMA inventories, although he is found in Kano and Segou records in WAAMD.

${ }^{133}$ To `Alī b. Abī Tālib are attributed many titles in the SAVAMA inventories, in all, 75 citations in 19 libraries.

134 Found in nine libraries, with 11 different titles, mainly qasidas in praise of the Prophet.

135 Core Curriculum, 173. Found in 21 libraries, 48 separate titles, from devotions to correspondence.

136 Core curriculum, 173. Found in 27 libraries, 318 citations on a wide variety of topics. 


\section{Sufism (tașawwuf)}

○ ‘Abd al-Qādir b. ‘Abd Allāh b. Mūsa al-Jaylānī, Qasìda al-Jaylānī and Qasìda al-ghuthiyya and Kitāb fath al-ghaib ${ }^{137}$

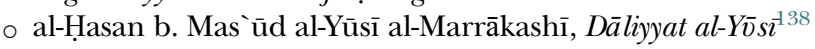

- Aḥmad b. Muḥammad b. ‘Abd al-Karīm b. 'Atțā' Allāh al-Iskandarī, Kitāb al-Hikam $^{139}$

- Aḥmad b. Aḥmad b. Muḥammad b. `Īsā b. Zarrūq al-Burnusī, Qawā 'id al-Zarrō q ${ }^{140}$

○ Yūsuf b. Sa ì̃d al-Filālī, al-Durur al-munazzama ${ }^{141}$

○ Ḥasan b. Ab̄̄ al-Qāsim b. Bādīs, al-Naf̣ha al-qudusiyya ${ }^{142}$

137 Found in 24 libraries in 182 citations; also found in four other WAAMD collections.

138 Core Curriculum, 173. Found in 25 libraries in 206 citations.

139 Core Curriculum, 172. Found in three libraries in three citations.

140 Core Curriculum, 172-173. 11 versions of this title are found in 12 libraries and throughout the WAAMD collections.

${ }^{141}$ Found in 18 libraries in 49 citations. This author and title are also cited in the Segou catalogue but found nowhere else in WAAMD.

${ }^{142}$ Found in 11 libraries in 14 citations, as well as Segou, Niamey, Nouakchott, and Kano. 


\begin{tabular}{|c|c|c|c|c|}
\hline & Library & $\begin{array}{c}\text { Total } \\
\text { manuscripts } \\
\text { in inventory }\end{array}$ & $\begin{array}{l}\text { Manuscripts with } \\
\text { author identified }\end{array}$ & $\begin{array}{c}\# \\
\text { manuscripts } \\
\text { entered in } \\
\text { WAAMD** }\end{array}$ \\
\hline 1 & Abu Bakr b. Sa'id Library & 7,609 & 1,370 & $7,609 *$ \\
\hline 2 & $\begin{array}{l}\text { Abd al-Mu'min, Zawiya Kunta } \\
\text { Library }\end{array}$ & 9,873 & 379 & 1,800 \\
\hline 3 & Cheickna Boulker Library & 1,500 & 225 & 206 \\
\hline 4 & al-Ṭāhir Mu‘ādh Library & 38,976 & 4,677 & 4,886 \\
\hline 5 & $\begin{array}{l}\text { Cheikh Ibrahim Alhassan } \\
\text { Library }\end{array}$ & 8,987 & 270 & 923 \\
\hline 6 & Mohamed Al-Hanafi Library & 10,981 & 329 & 1,095 \\
\hline 7 & Mas`ūd b. Abī Bakr Library & 6,856 & 686 & 1,899 \\
\hline 8 & Sidi Zayan Library & 4,987 & 349 & 1,350 \\
\hline 9 & Abu Bakr b.'Abbas Library & 13,987 & 560 & 1,088 \\
\hline 10 & Aḥmad Bū al-`Arāf Library & 3,589 & 431 & 1,278 \\
\hline 11 & Alfa Mahamane Library (Diré) & 8,445 & 760 & 1,960 \\
\hline 12 & Infa Yatara Library & 3,796 & 607 & 1,613 \\
\hline 13 & Alfā al-Ṭayib Library & 9,985 & 499 & 1,026 \\
\hline 14 & Aḥmad Cisse Tonka Library & 5,883 & 588 & 760 \\
\hline 15 & $\begin{array}{l}\text { al-Qāọī `Isa al-Arawānī } \\
\text { Library }\end{array}$ & 3,262 & 130 & 142 \\
\hline 16 & Imām Alfā Saloum Library & 9,897 & 693 & 1,253 \\
\hline 17 & $\begin{array}{l}\text { Imām Dawūd Muḥammad } \\
\text { Library }\end{array}$ & 8,986 & 270 & 456 \\
\hline 18 & $\begin{array}{l}\text { Mohamed Aldjoumatt } \\
\text { Library }\end{array}$ & 13,558 & 271 & 697 \\
\hline 19 & Mogaz Annouwaye Library & 23,877 & 955 & 1,030 \\
\hline 20 & Mūlāy Rashīd Library & 7,648 & 382 & 664 \\
\hline 21 & Abdoul Kader Cissé Library & 9,998 & 395 & 1,022 \\
\hline 22 & Alpha Mody Library & 4,069 & 122 & 271 \\
\hline 23 & $\begin{array}{l}\text { Aboubacar Ben Mahamane } \\
\text { Hassey }\end{array}$ & 6,832 & 273 & 767 \\
\hline 24 & $\begin{array}{l}\text { Almater Mohamed Ibrahim } \\
\text { Library }\end{array}$ & 14,397 & 576 & 2,627 \\
\hline 25 & Cheik Hama Hama Library & 9,963 & 299 & 545 \\
\hline 26 & $\begin{array}{l}\text { Mohamed Ould Ousmane } \\
\text { Library }\end{array}$ & 4,948 & 405 & 766 \\
\hline 27 & $\begin{array}{l}\text { Abdoullah b. Abd Raḥmane } \\
\text { Library }\end{array}$ & 12,562 & 1,510 & 4,236 \\
\hline
\end{tabular}




\section{(Continued)}

\begin{tabular}{|c|c|c|c|c|}
\hline & Library & $\begin{array}{l}\text { Total } \\
\text { manuscripts } \\
\text { in inventory }\end{array}$ & $\begin{array}{l}\text { Manuscripts with } \\
\text { author identified }\end{array}$ & $\begin{array}{c}\# \\
\text { manuscripts } \\
\text { entered in } \\
\text { WAAMD** }\end{array}$ \\
\hline 28 & $\begin{array}{l}\text { Almoustapha Abdoulahi } \\
\text { Library }\end{array}$ & 14,442 & 446 & 828 \\
\hline 29 & $\begin{array}{l}\text { Cady Ahmed Baba Aboul } \\
\text { Abass }\end{array}$ & 5,317 & 513 & 1,109 \\
\hline 30 & $\begin{array}{l}\text { UUmar b. Ibrāhīm Shaykh } \\
\text { Library }\end{array}$ & 8,637 & 183 & 625 \\
\hline 31 & Sīdī Igoumo Library & 4,071 & 113 & 265 \\
\hline 32 & Mouhamad Sidik Library*** & 8,740 & 729 & 8,129 \\
\hline 33 & Mamma Haidara Library & 41,935 & inventory not entered & \\
\hline 34 & Hamane Sidi Elmiki & 7,835 & inventory incomplete & \\
\hline 35 & Mahamane Fondo Goumo & 2,000 & inventory incomplete & \\
\hline
\end{tabular}

*The entire contents of the Abu Bakr b. Sa'id Library were entered; thereafter, only items with author attribution and more than two folios were entered.

${ }^{* *}$ Apart from the Abu Bakr b. Sa'id Library, this number includes all manuscripts with more than two folios and all manuscripts with identified authors.

${ }^{* * *}$ There are several anomalies in this library inventory that were being resolved at the time this analysis was done; it is not included in the statistics above. It is distinguished from the others by being mainly correspondence about commercial matters.

\section{References}

Assuyuti, Imam, "Catalogue de la Bibliotheque Imam Essayouti, Tombouctou," https://www.worldcat.org/title/fihrist-i-nuskhahha-yi-khatti-i-kitabkhanah-ial-imam-al-suyuti-tumbuktu, (Qum: 2010).

Bondarev, Dmitry, "Tafsìr Sources in Four Annotated Qur'anic Manuscripts from Early Borno," in Jirji, Zulfiqar (ed.), Approaches to the Qur'an in sub-Saharan Africa (Oxford: Oxford University Press, 2019).

- "Qur'anic Exegesis in African languages." Special Issue of the Journal of Qur'anic Studies (2013).

Center for the Study of Manuscript Cultures (CSMC), "Handlist of Manuscripts" (25 October 2019), https://www.manuscript-cultures.uni-hamburg.de/tim buktu/handlists_e.html, (accessed 10 March 2021).

English, Charlie, The Storied City: The Quest for Timbuktu (New York: Riverhead, 2017).

Ghali, Noureddine, Sidi Mohamed Mahibou, and Louis Brenner, Inventaire de la Bibliothèque 'Umarienne de Segou (Paris: CNRS, 1985).

Goody, Jack, and Ian Watt, "The consequences of literacy," Comparative Studies in Society and History 5 no. 3 (Apr. 1963). 
Godwin, Nick, "The Road to Timbuktu," in Wonders of the African World, DVD (1999; Alexandria, VA: PBS Home Video, 2004).

Haidara, Abdel Kader, "The state of manuscripts in Mali and efforts to preserve them," in Jeppie, Shamil and Souleymane Bachir Diagne (eds.), The Meanings of Timbuktu (Cape Town: HSRC Press, 2008), 265-270.

_ Kratli and Ghislaine Lydon (eds.), The Trans-Saharan Book Trade (Leiden: Brill, 2011), 241-264.

Haidara, Ismaël Diadié, et al., Fondo Kati, Trésors cachés de Tombouctou, https:// www.worldcat.org/title/khazain-i-maktum-i-tumbuktu-fihristvarah-i-umumi-inuskhahha-yi-khatti-i-fandikati-khandan-i-al-quti, (Qum: 2012).

Hall, Bruce, "Rethinking the Place of Timbuktu in the Intellectual History of Muslim West Africa," in Green, Toby and Benedetta Rossi (eds.), Landscapes, Sources and Intellectual Projects of the West African Past (Leiden: Brill, 2018), 239-258.

Hall, Bruce S., and Charles C. Stewart, "The Historic Core Curriculum and the Book Market in Islamic West Africa," in Graziano Kratli and Ghislaine Lydon (eds.), The Trans-Saharan Book Trade (Leiden: Brill, 2011), 109-174.

Hammer, Joshua, The Bad-Ass Librarians of Timbuktu (New York: Simon and Schuster, 2016).

Hawkes, Sharron, The Ancient Astronomers of Timbuktu, DVD (Parklands, South Africa: Dogged Films, 2009).

Hunwick, J.O., The Hidden Treasures of Timbuktu (London: Thames \& Hudson, 2008).

Institut des hautes études et de recherches islamiques Ahmed Baba, Fihris makhtütāt Ma'had Aḥmad Bābā lil-Dirāsāt al-'Ulyā wa-al-Buhūth al-Islāmīyah (Timbuktu: 2016).

Jeppie, Shamil and Souleymane Bachir Diagne (eds.), The Meanings of Timbuktu (Cape Town: HSRC Press, 2008).

Maseko, Zola, The Manuscripts of Timbuktu, DVD (San Francisco, CA: California Newsreel, 2009).

Naylor, Paul, "West African Esoteric Material (Fawā'id): identification, content and cataloging strategy," presentation at the workshop, Working with Arabic-script Manuscripts in Africa, Northwestern University, 15 August 2017.

Ngom, Fallou and Mustapha Kurfi (eds.), “Ajamization of Islam in Africa, ” Special Issue, Islamic Africa 8, no. 1-2 (2017).

Stewart, Charles C., Arabic Literature of Africa, vol. V: The Writings of Mauritania and the Western Sahara (Leiden: Brill, 2016).

—, "Calibrating the scholarship of Timbuktu," in Green, Toby and Benedetta Rossi (eds.), Landscapes, Sources and Intellectual Projects of the West African Past (Leiden: Brill, 2018), 220-238.

, "Évaluer le Niveau de la Culture Savante à Tombouctou," Islam et sociétés au sud du Sahara V (2018), 57-77.

- "A comparison of the exercise of colonial and precolonial justice in Mauritania," in Edmond Bernus, et al. (eds.), Nomades et commandants administration et sociétiés nomads dans l'ancienne A.O.F. (Paris: Karthala, 1993), 81-86.

Tamari, Tal, "La prose littéraire arab en traduction Bambara: une maqama d'alHariri", in Baumgardt, Ursula and Jean Derive (eds.), Paroles nomads. Ecrits d'ethnolinguistique en homage à Christiane Seydou (Paris: Karthala, 2005), 431-463.

—_, "A Bamana Commentary on Sūrat Al-Wāqiia (Q. 56): A Linguistic and Stylistic Analysis," Journal of Qur'anic Studies 15, no. 3 (2013), 123-183. 
Trayler-Smith, Richard, BBC: The Lost Libraries of Timbuktu, DVD (Princeton, NJ: Films for the Humanities \& Sciences, 2009).

Triaud, Jean-Louis, "Tombouctou ou le Retour du Mythe: L'Exposition Médiatique des Manuscrits de Tombouctou," in Gary-Tounkara, Daouda, and Didier Nativel, (eds.), Afrique des Savoirs au Sud du Sahara (Paris: Karthala, 2012), 201-222.

— , "Autour des manuscrits de Tombouctou, Un état des lieux," Sociétés politiques comparées 44 (Jan.-April 2018).

West African Arabic Manuscript Database (WAAMD), https://waamd.lib.berkeley. edu/ 